AperTO - Archivio Istituzionale Open Access dell'Università di Torino

\begin{abstract}
Italian Association of Clinical Endocrinologists (AME) \& Italian Association of Clinical Diabetologists (AMD) Position Statement : Diabetes mellitus and thyroid disorders: recommendations for clinical practice.
\end{abstract}

This is the author's manuscript

Original Citation:

Availability:

This version is available http://hdl.handle.net/2318/1508838

since 2016-06-29T13:15:48Z

Published version:

DOI:10.1007/s12020-014-0474-9

Terms of use:

Open Access

Anyone can freely access the full text of works made available as "Open Access". Works made available under a Creative Commons license can be used according to the terms and conditions of said license. Use of all other works requires consent of the right holder (author or publisher) if not exempted from copyright protection by the applicable law. 
This is the author's final version of the contribution published as:

Guastamacchia E;Triggiani V;Aglialoro A;Aiello A;Ianni L;Maccario M;Zini M;Giorda C;Guglielmi R;Betterle C;Attanasio R;Borretta G;Garofalo P;Papini E;Castello R;Ceriello A. Italian Association of Clinical Endocrinologists (AME) \& Italian Association of Clinical Diabetologists (AMD) Position Statement : Diabetes mellitus and thyroid disorders: recommendations for clinical practice.. ENDOCRINE. 49 (2) pp: 339-352. DOI: $10.1007 / \mathrm{s} 12020-014-0474-9$

The publisher's version is available at:

http://link.springer.com/content/pdf/10.1007/s12020-014-0474-9

When citing, please refer to the published version.

Link to this full text:

http://hdl.handle.net/2318/1508838 


\title{
Italian Association of Clinical Endocrinologists (AME) \& Italian Association of Clinical Diabetologists (AMD) Position Statement
}

Diabetes mellitus and thyroid disorders: recommendations for clinical practice Edoardo Guastamacchia, Vincenzo Triggiani, Alberto Aglialoro, Antimo Aiello, Lucia lanni, Mauro Maccario, Michele Zini, Carlo Giorda, Rinaldo Guglielmi, Corrado Betterle, Roberto Attanasio, Giorgio Borretta, Piernicola Garofalo, Enrico Papini, Roberto Castello, Antonio Ceriello

\begin{abstract}
Thyroid disease and diabetes mellitus, the most common disorders in endocrine practice, are not infrequently associated in the same subject. An altered thyroid function may affect glucose tolerance and worsen metabolic control in patients with diabetes. Thyrotoxicosis increases the risk of hyperglycemic emergencies, while a clinically relevant hypothyroidism may have a detrimental effect on glycemic control in diabetic patients. The association of alterations in thyroid function with diabetes mellitus may adversely affect the risk of cardiovascular and microvascular complications resulting from diabetes. Moreover, the treatments used for both diabetes and thyroid disease, respectively, can impact one other. Finally, multinodular goiter, but not thyroid carcinoma, was shown to be more prevalent in type 2 diabetes mellitus. Aim of the present Position Statement is to focus on the evidence concerning the association of thyroid disease and diabetes mellitus and to provide some practical suggestions for an updated clinical management.
\end{abstract}

\section{Abbreviations}

ADA

American Diabetes Association

AITD

Autoimmune thyroid disease

APS

Autoimmune polyglandular syndrome

BMI

Body mass index

CTLA-4

Cytotoxic T-lymphocyte antigen 4

CV

Cardiovascular

CVD

Cardiovascular diseases 
DIO

Deiodinase

DKA

Diabetic ketoacidosis

ELISA

Enzyme-linked immunosorbent assay

FT3

Free tri-iodothyronine

FT4

Free thyroxine

GAD-Abs

Glutamic acid decarboxylase antibodies

GDM

Gestational diabetes mellitus

GLP-1

Glucagon-like peptide 1

GLUT

Glucose transporter

GO

Graves' orbitopathy

HDL

High-density lipoprotein

IA2

Islet antigen-2

IAA

Insulin antibody 
ICA

Islet cell antibody

IGT

Impaired glucose tolerance

LDL

Low-density lipoprotein

LoE

Evels of evidence

MEN

Multiple endocrine neoplasia

OGTT

Oral glucose tolerance test

OR

Odds ratio

PPTD

Post-partum thyroid dysfunction

SU

Sulfonylureas

T1DM

Type 1 diabetes mellitus

T2DM

Type 2 diabetes mellitus

T3

Tri-iodothyronine

$\operatorname{TgAb}$

Anti-thyroglobulin antibodies 
TPOAb

Anti-thyroperoxidase antibodies

TRAb

Anti-TSH receptor antibodies

TSH

Thyrotropin

\section{Why a consensus document on thyroid disease and diabetes mellitus?}

Thyroid disease and diabetes mellitus (DM) are the most common endocrine disorders in clinical practice and are often associated in the same individual. In some cases, there is a common genetic/epigenetic substrate, while in others the association stems from the increased incidence of these pathologic conditions with advancing age.

The GRADE (Grading of recommendation, assessment, development, and evaluation) system was adopted in the preparation of the present document to ensure a well-balanced assessment of the data from the available literature. Briefly, the GRADE system classifies evidence into four quality levels (very low, low,

moderate, or high, using the following symbols, respectively, LoE , , , , and recommendations into two grades (strong or weak). The strong and weak recommendations are labeled as "recommendations" and "suggestions", respectively. Each recommendation/suggestion is based on the quality of supporting evidence and downgraded or upgraded according to adjunctive factors (e.g., inconsistent results, indirect evidence, lack of precision, and limited number of relevant publications downgraded the recommendations/suggestions while large effect size, narrow confidence intervals, and clinically significant endpoints upgraded the recommendations/suggestions) and the level of panel agreement [1-5].

\section{Epidemiology of diabetes mellitus and the association with thyroid disease}

In iodine-replete areas, the prevalence of spontaneous hypothyroidism is 1-2 \%, and it is ten times more common in women, especially in the elderly [6], while lower figures have been reported in areas of iodine deficiency [7]. In the Whickham Survey in Northeast England, $8 \%$ of women and $3 \%$ of men had subclinical hypothyroidism [8], and the annual incidence of spontaneous hypothyroidism was, respectively, 3.5/1,000 and 0.6/1,000 during a 20-year follow-up [9]. A higher prevalence (about $10 \%$ ) was found in studies of elderly persons [10]. Data from the Whickham cohort showed a prevalence of $4.7 / 1,000$ and an incidence of $0.8 / 1,000 /$ year for hyperthyroidism in women, with negligible figures in men [8,9]. In an iodine deficient community of Southern Italy, the reported prevalence of hyperthyroidism was $2.9 \%$ [7].

In Italy, more than 3 million individuals are affected with diabetes, which is about $5.5 \%$ of the general population. Of this group, a non-negligible portion [approximately 250,000 individuals (7.6\%)] have type 1 diabetes (T1DM) [11]. It is noteworthy that the prevalence of alterations of thyroid function in patients with DM is higher than in the general population [12-15]. In an observational study of 1,301 adults with diabetes, an average prevalence of altered thyroid function was reported (13.4 \%) higher in women with T1DM (31.4 \%) and lower in males with type 2 diabetes (T2DM, $6.9 \%$ ) [16]. A meta-analysis of 10,920 diabetic patients showed an average frequency of thyroid disease of $11 \%$ with no difference between T1DM and T2DM, but with a higher prevalence in women [15]. Autoimmune thyroid diseases (AITDs) are the most frequent autoimmune pathologies associated with T1DM [17]. Table 1 reports the prevalence of 
AITD in T1DM patients. The frequency of clinical, latent, or potential AITD is extremely variable (range, 3.9$24 \%$ ) in different studies because of differences in study populations regarding age (children, adolescents, or adults), ethnic group, number of subjects, different methods of thyroid auto-antibodies determination, evaluation of thyroid auto-antibodies also in the non-diabetic population, and TSH determinations [18].

Table 1 Frequency of AITD in more than 52,000 T1DM patients

\begin{tabular}{|c|c|c|c|c|c|c|c|c|}
\hline Year & Author (ref) & $\begin{array}{l}\text { No. of } \\
\text { cases }\end{array}$ & Age & $\begin{array}{c}\text { Thyroid } \\
\text { antibodies only } \\
\text { (\%) }\end{array}$ & $\begin{array}{c}\text { Clinical } \\
\text { hypothy- } \\
\text { roidism (\%) }\end{array}$ & $\begin{array}{c}\text { Clinical } \\
\text { hyperthy- } \\
\text { roidism (\%) }\end{array}$ & $\begin{array}{l}\text { Subclinical thyroid } \\
\text { dysfunction (\%) }\end{array}$ & $\begin{array}{c}\text { Total } \\
\text { AITD } \\
\text { (\%) }\end{array}$ \\
\hline 1963 & Moore [19] & 33 & Adults & 15.0 & 3.0 & n.r. & n.r. & 18.0 \\
\hline 1970 & Goldstein [20] & 155 & Children & 8.0 & n.r. & n.r. & n.r. & n.r. \\
\hline 1970 & Irvine [21] & 671 & All ages & 17.5 & n.r. & n.r. & n.r. & n.r. \\
\hline 1973 & Nerup [22] & 66 & n.r. & 17.0 & n.r. & n.r. & n.r. & n.r. \\
\hline 1980 & Neufeld [23] & 504 & Children & 17.0 & n.r. & n.r. & n.r. & n.r. \\
\hline 1981 & Riley [24] & 771 & Children & 17.6 & n.r. & n.r. & n.r. & \\
\hline 1982 & Court [25] & 134 & Children/adults & 10.4 & 2.2 & n.r. & n.r. & 12.6 \\
\hline 1982 & Kokkonen [26] & 84 & $12-19$ years & 11.9 & 0.0 & n.r. & n.r. & 11.9 \\
\hline 1984 & Gilani [27] & 58 & $1-18$ years & 12.0 & 3.5 & n.r. & n.r. & 15.5 \\
\hline 1985 & Maclaren [28] & 1,456 & All ages & 23.0 & n.r. & n.r. & n.r. & n.r. \\
\hline 1987 & Drell [29] & 3,779 & n.r. & 17.9 & n.r. & n.r. & n.r. & n.r. \\
\hline 1990 & Kontiainen [30] & 133 & Children & 24.0 & n.r. & n.r. & n.r. & n.r. \\
\hline 1992 & $\begin{array}{l}\text { Landin-Ollson } \\
\text { [31] }\end{array}$ & 473 & $15-34$ years & 5.0 & n.r. & n.r. & n.r. & n.r. \\
\hline 1995 & Radetti [32] & 1,419 & Children & 2.5 & 0.07 & 0.07 & 1.3 & 3.9 \\
\hline 1995 & Perros [16] & 406 & Adults & n.r. & 10.5 & 4.2 & 8.1 & n.r. \\
\hline 1995 & Abrams [33] & 157 & 10-39 years & 17.1 & n.r. & n.r. & n.r. & n.r. \\
\hline 1996 & Jefferson [34] & 974 & Children & n.r. & 2.2 & 0.2 & n.r. & n.r. \\
\hline 1996 & Lorini [35] & 212 & Children/adolescents & 16.4 & n.r. & 0.4 & n.r. & 16.8 \\
\hline 1997 & Presotto [36] & 1,741 & All ages & 11.8 & 0.8 & 1.6 & n.r. & 14.1 \\
\hline 1998 & McCanlies [37] & 265 & Children & n.r. & 15.1 & 9.3 & 11.5 & n.r. \\
\hline 1998 & Chang [38] & 243 & n.r. & 21.8 & n.r. & n.r. & n.r. & 21.8 \\
\hline 1999 & Hansen [39] & 105 & Children & 13.3 & 0.9 & n.r. & 1 & 15.2 \\
\hline 1999 & Roldan [40] & 204 & $<20$ years & n.r. & n.r. & n.r. & n.r. & 17.6 \\
\hline 2000 & $\begin{array}{l}\text { Gambelunghe } \\
\text { [41] }\end{array}$ & 67 & Adults & 12.0 & 6.0 & 1.5 & 4.5 & 24.0 \\
\hline 2000 & $\begin{array}{l}\text { Rattarasarn } \\
\text { [42] }\end{array}$ & 50 & All ages & 32.0 & n.r. & n.r. & n.r. & n.r. \\
\hline 2001 & De Block [43] & 399 & All ages & 17.0 & 4.0 & 3.0 & n.r. & 24.0 \\
\hline 2002 & $\begin{array}{l}\text { Kordonouri } \\
{[44]}\end{array}$ & 7,097 & Children/adolescents & 21.6 & n.r. & n.r. & n.r. & n.r. \\
\hline 2004 & Barova [45] & 210 & All ages & 29.6 & n.r. & n.r. & n.r. & n.r. \\
\hline 2005 & Prazny [46] & 51 & Adults & 13.7 & 7.8 & 0 & 2.0 & 22.5 \\
\hline 2005 & Vondra [47] & 49 & $18-35$ years & 26.5 & n.r. & n.r. & n.r. & n.r. \\
\hline 2005 & Barker [48] & 814 & Children & 29 & n.r. & n.r. & n.r. & n.r. \\
\hline 2006 & Volzke [49] & 224 & Adults & 19.6 & 0.9 & 0.4 & 3.5 & n.r. \\
\hline 2007 & Mantovani [50] & 383 & Children/adolescents & 16.7 & n.r. & n.r. & 7.3 & n.r. \\
\hline 2010 & Warncke [51] & 28,671 & All ages & 19.6 & n.r. & n.r. & n.r. & n.r. \\
\hline & All cases & 52,058 & & $2.5-32$ & $0-15.1$ & $0.07-9.3$ & $1-11.5$ & $3.9-24$ \\
\hline
\end{tabular}


In AITD patients, both T1DM and/or anti-pancreas auto-antibodies are more prevalent compared to the general population. In fact, T1DM occurs in 3-8 \% of patients affected by chronic autoimmune thyroiditis and in $1-5 \%$ of patients with Graves' disease [11, 39, 52-54]. Furthermore, markers of autoimmune diabetes are frequently found in patients with AITD without clinical diabetes at the following rates: ICA in $1.3-19 \%[53,55-60]$, GAD-Abs in 5.1-11 \% [53, 61, 62], IA2 antibodies in 0.9-4 \% [63, 64], and IAA in 3.8$3.9 \%$ [61].The risk of AITD patients with positive anti-pancreas antibodies developing T1DM is increased with higher ICA titles and family history of $\operatorname{T1DM}[65,66]$ and is directly correlated to the number of positive serological pancreatic autoimmune markers [67]. Therefore, patients with AITD should be carefully evaluated for clinical, latent, or potential T1DM, and vice versa.

The frequency of thyroid dysfunction in T2DM patients appears to be equal to that of T1DM patients, probably due to the older age of the former $[68,69]$. Hypothyroidism is the most common form of thyroid dysfunction in diabetic patients, with a prevalence of $5.7 \%$ [16]. Prevalence was reportedly $8.6 \%$ in the female diabetic population [69] and $6 \%$ in diabetic adolescents [70]. The study conducted by Díez et al. [71] on 2023 subjects showed a significantly increased risk of hypothyroidism in patients with T2DM over 65 years of age [odds ratio (OR), 4.2] with clear differences between males and females (OR 4.82 vs. 2.60), obese and non-obese (OR 2.56 vs. 3.11) patients, with and without thyroid auto-antibodies (OR 4.26 vs. 2.93). The development of hypothyroidism seems to be directly related to autoimmune thyroiditis, macroangiopathy, and treatment with metformin. These data suggest the opportunity of screening for hypothyroidism in patients with T2DM over 65 years of age, especially in the presence of macrovascular complications or metformin treatment.

The prevalence of hyperthyroidism in subjects with diabetes is about $1 \%$ higher than in the general population [16]. In patients with T2DM, the prevalence of newly diagnosed subclinical hyperthyroidism is reportedly $4.3 \%$ in females and $3.5 \%$ in males, with relative risk significantly increased only in females [72]. As compared to diabetic patients without hyperthyroidism, those with subclinical hyperthyroidism were older, had a longer duration of diabetes, lower values of fasting blood glucose, a higher prevalence of goiter, and were more often on diet therapy. Multivariate analysis shows that age and the presence of goiter are significantly correlated with subclinical hyperthyroidism in patients with T2DM. In conclusion, advanced age and the presence of goiter are significantly and independently correlated with the presence of subclinical hyperthyroidism in the diabetic population.

The presence of T2DM does not predict the incidence of thyroid dysfunction in the elderly diabetic population [73]. Moreover, there seems to be no relationship between thyroid disease and clinical parameters related to diabetes, such as duration of disease, degree of glycemic control, and presence of complications [74].

\section{Clinical implications of the association between thyroid dysfunction and diabetes mellitus}

\section{Genetics: polyendocrine autoimmune syndromes}

T1DM and AITD are two conditions mediated by organ-specific T-cells. They may not infrequently occur in the same individual or in his/her family members [75, 76], suggesting a common genetic susceptibility. This increased susceptibility for autoimmune diseases seems confirmed by a body of data. The prevalence of autoimmune thyroiditis and/or thyroid antibodies in patients with T1DM can be as high as $48 \%$ compared with $3-10 \%$ in the general population. The incidence of post-partum thyroiditis in patients with T1DM is three times that observed in the general population [77]. Auto-antibodies (TPOAb and TgAb) are more frequent in patients with T1DM and their first-degree relatives [78], and their presence seems to predict a higher risk of thyroid dysfunction [79-82]. As for the influence of epigenetic factors, the risk of AITD in a family whose father is affected by T1DM increases by $6 \%$ as compared to $3 \%$ if the mother is affected. Despite the strong genetic association, knowledge is lacking in regards to the genetic transmission of the combined susceptibility for T1DM and AITD [14]. A genome-linkage-scan of 88 multi-generational families 
with diabetes and thyroiditis has shown that HLAII, CTLA4, FOXP3, and PTPN22 are the major genes involved in susceptibility to joint T1DM and AITD [83]. Numerous other loci have been proposed for potential genetic susceptibility $[14,84]$.

The co-existence of T1DM and AITD in the same patient is a variant of autoimmune polyglandular syndrome (APS), type 3 (APS-3 variant). More than one third of patients with T1DM develop APS. In addition to possible AITD (Hashimoto's thyroiditis or Graves' disease) in 15-30 \% of cases, autoimmune gastritis and/or pernicious anemia (5-10\%), celiac disease (4-9\%), vitiligo (2-10\%), or Addison's disease (0.5\%) [85-87] may occur.

In clinical practice, it is useful to screen T1DM patients. According to the American Diabetes Association (ADA) [88] and the Canadian Diabetes Association [89], the screening should include TSH, TPOAb, and TgAb. The ADA specifies that TSH should be measured after obtaining satisfactory glycemic control. Long-term follow-up should include a periodic assessment of thyroid function (with TSH and TPOAb determination). Thus, tests should be run at 1 to 2-year intervals if TPOAbs are initially negative, and more frequently (up to every 6 months) if TPOAbs are positive or if there are symptoms of dysfunctional goiter or, in pediatric age, there is a reduction in linear growth $[85,88,89]$. Besides clinical evaluation, the possible coexistence or potential onset of T1DM in AITD patients, especially in case of younger subjects and/or family history of T1DM, can be evaluated by measuring fasting glucose, glycated hemoglobin (A1C) and ICA and GAD-Abs at the time of diagnosis of AITD. Re-evaluation for T1DM over the time should be based on initial findings: positive ICA and/or GAD-Abs subjects require careful clinical follow-up and periodic glucose determinations; in patients with initial normal findings further evaluation can rely on clinical findings. In case of a T1DM-AITD association, a genetic study of the patient is advised along with a serological screening of first-degree relatives in the context of probable APS, taking into account-related costs, and the availability of qualified centers.

Genetic correlations are less well characterized in T2DM. Recent data suggest that homozygosis for Thr92Ala polymorphism of the gene encoding type 2 deiodinase (DIO2) is associated with an increased risk of T2DM [90]. These findings are supported by a meta-analysis of 11,000 individuals and point to a possible role for tri-iodothyronine (T3) in modulating insulin sensitivity [15].

\section{Indications for clinical practice}

1. (1)

In T1DM patients, as well as in subjects with latent autoimmune diabetes of the adult, at initial diagnosis we recommend serological screening that includes TSH, TPOAb, and TgAb (especially in TPOAb-negative children). We suggest that the subsequent follow-up include annual monitoring of thyroid function with a TSH determination if TPOAb and/or TgAb were positive in the presence of euthyroidism; in patients with negative anti-thyroid antibodies TSH should be re-evaluated after 23 years.

2. (2)

We suggest to evaluate in patients with AITD, especially in case of younger subjects and/or family history of T1DM, the possible coexistence or potential onset of T1DM by measuring fasting glucose, A1c and ICA and GAD-Abs at the time of diagnosis of AITD. We suggest to carefully re-evaluate (fasting glucose and A1c) over the time subjects with positive ICA and/or GAD-Abs; in patients with initial normal findings further evaluation can rely on clinical findings. 
3. (3)

We suggest that T1DM patients, with or without concomitant AITD, should be evaluated for associated autoimmune diseases. The evaluation of autoimmune gastritis should be performed by determination of anti-gastric parietal cell autoantibodies, gastrinemia, and red blood cell evaluation and, in case of anemia and/or hypergastrinemia, gastric endoscopy. The evaluation of celiac disease should be performed by determination of IgA and IgG anti-transglutaminase antibodies, and, if positive, gastric and duodenal endoscopy with biopsy. All these investigations should be performed at the onset of T1DM and periodically repeated (every 2-3 years) if initially negative.

\section{Hyperthyroidism and diabetes}

An increased risk of severe hyperglycemia, occasionally complicated by ketoacidosis, is well established in diabetic patients with thyrotoxicosis when compared to diabetic patients with normal thyroid function [15, 91]. Key events are increased hepatic glucose production and intestinal glucose absorption, lower insulin half-life due to increased rate of degradation, release of insulin precursors, and biologically inactive proinsulin [92]. Hyperthyroidism is associated with increasing insulin resistance [93-95]. In T2DM, serum insulin levels are reported to increase after the appearance of a thyrotoxic state. This alteration is readily corrected by the restoration of normal thyroid function [96]. For these reasons, new onset hyperglycemia in a hyperthyroid subject should be re-evaluated after the correction of thyroid dysfunction [97]. Hyperthyroidism considerably worsens metabolic control in diabetic patients and can be a precipitating factor leading to diabetic ketoacidosis (DKA). Whenever DKA has no apparent trigger, thyrotoxicosis should be ruled out as one of the potential precipitating factors [98, 99]. The clinical diagnosis of diabetes may be delayed in patients with thyrotoxicosis while, on the other hand, the clinical picture of decompensated diabetes may mask symptoms of thyrotoxicosis. Unfortunately, serum thyroid hormone assay during the state of DKA can provide unreliable results due to low-T3 syndrome [100].

Prevalence of Graves' orbitopathy (GO) is reportedly higher in subjects with T1DM, due to both the common autoimmune basis and the potential role played by diabetic microangiopathy. The prevalence of dysthyroid optic neuropathy is higher owing to the greater vulnerability of the optic nerve to endo-orbital pressure; the prognosis is worse in patients with GO associated with DM compared to patients with GO alone [54]. Finally, in patients with T2DM, the coexistence of hyperthyroidism may increase the already high risk of cardiovascular disease (CVD) [101-104].

\section{Indications for clinical practice}

We suggest the evaluation of thyroid function during DKA to rule out an unapparent hyperthyroidism. The hormonal profile should be cautiously considered due to frequent coexistence of a low-T3 syndrome.

We suggest an adjustment of therapy in patients with diabetes after the occurrence of hyperthyroidism. 
(3)

We suggest considering diabetic patients with hyperthyroidism, especially if aged or with previous CVD or atrial fibrillation, as a group at high risk of adverse cardiovascular outcomes.

(4)

We recommend re-evaluating newly detected hyperglycemia in hyperthyroid subjects after control of thyroid dysfunction.

\section{Hypothyroidism and diabetes}

Clinical hypothyroidism is a condition characterized by insulin resistance due to the decreased ability of insulin-mediated translocation of glucose by glucose transporter 4 (GLUT-4) [105-107]. The deficiency of thyroid hormones seems to reduce the expression of sodium-dependent GLUT-4 of the brush border of bowel cells, which may reduce intestinal glucose absorption [107]. Furthermore, hypothyroidism is associated with a reduction in hepatic glucose production [107]. Therefore, the lowest capacity to metabolize (and utilize) glucose in the periphery is balanced by a reduced hepatic glucose production and by the lower intestinal absorption of carbohydrates. In diabetic patients treated with glucose-lowering drugs, the development of hypothyroidism may potentially lead to an increased risk of hypoglycemia due to reduced endogenous production of glucose $[12,70]$. In case of insulin resistance, impaired glucose tolerance (IGT), or overt diabetes, an assessment of thyroid function is recommended; in case of hypothyroidism, a glucometabolic evaluation (oral glucose tolerance test, OGTT) should be repeated after restoring normal thyroid function [105].

Poor metabolic control of T2DM is frequently associated with transient abnormalities of thyroid function: TSH levels in the range of subclinical hypothyroidism are reversed to normal with the improvement of the glucometabolic state [104]. Moreover, uncontrolled diabetes may dampen the effectiveness of I-thyroxine treatment in hypothyroidism [12, 70, 104]. Overt hypothyroidism, due to possible deranging effects in dyslipidemia, hypertension, and insulin resistance, may increase the CV risk associated with diabetes [108]. The lipid profile is only partially normalized by l-thyroxine replacement therapy. Low-density lipoprotein cholesterol and non-high-density lipoprotein cholesterol targets in subjects at high CV risk, such as those with T2DM $(<100 \mathrm{mg} / \mathrm{dL}$ and $<130 \mathrm{mg} / \mathrm{dL}$, respectively), require combination therapy to achieve a further $10-20 \%$ reduction [109].

The risk of statin-induced myopathy is greater in hypothyroid subjects [110, 111]. Accordingly, a lower statin dose should be administered in combination with other lipid-lowering treatments, if needed [108, 111-118].

The rate of progression from subclinical to overt hypothyroidism is similar in diabetic patients and in the general population [15]. In case of positive TPOAb $[9,69,119]$, monitoring of TSH should be performed at 6 - to 12 -month intervals. There are no reliable data concerning the role played by subclinical hypothyroidism on metabolic control $[70,120]$ and $C V$ risk in diabetes $[9,69,108,112,121]$. Although there is no clear evidence of benefit yet, cautious replacement therapy should be considered in light of high CV risk $[122,123]$. Both subclinical and overt hypothyroidism appear to be an adjunctive risk factor for the occurrence of diabetic nephropathy and retinopathy. However, there is no clear evidence that I-thyroxine replacement therapy can reduce the risk and/or progression of diabetic microvascular complications [124130]. 


\section{Indications for clinical practice}

(1)

In case of repeated hypoglycemic episodes, especially in T1DM patients, we suggest to rule out hypothyroidism by assaying serum TSH.

(2)

In patients with dyslipidemia, we recommend the use of statins only after TSH determination and correction of possible hypothyroidism to prevent the risk of myopathy.

(3)

In diabetic patients with subclinical hypothyroidism, we recommend a TSH check every 6 months for possible progression to overt hypothyroidism and the consequent changes in insulin resistance.

(4)

The correction of subclinical hypothyroidism in the course of DM may be considered even if serum TSH is 5-10 mIU/L, especially if associated with symptoms, goiter, or the desire for pregnancy.

(5)

We recommend evaluating TSH in patients with insulin resistance, IGT, or overt diabetes. We suggest to repeat a glucometabolic evaluation (OGTT) after restoring normal thyroid function in hypothyroid patients.

\section{Diabetes and disorders of thyroid function in pregnancy and post-partum}

A modestly increased risk of gestational diabetes mellitus (GDM) might be present in pregnant women with subclinical hypothyroidism compared to euthyroid pregnant women [131]. The incidence of thyroid dysfunction during pregnancy in diabetic women is three times higher than in the general female population, particularly in the first trimester of pregnancy and in the first year post-partum [77]. Up to $25 \%$ of women with T1DM may develop post-partum thyroid dysfunction [132] due to the rebound effect of autoimmune processes in the post-partum period in subjects with undiagnosed Hashimoto's thyroiditis.

Women with T1DM show TPOAbs more frequently during pregnancy compared to non-diabetic pregnant women [132-134]. The finding of elevated serum TSH levels associated with AITD in the early phase of pregnancy has also been associated with increased risk of GDM $[66,135]$. Women with T1DM and positive TPOAb thyroid function should be monitored by TSH determination at 3, 6, and 12 months after delivery [136]. 
(1)

We recommend TSH and TPOAb determination in women with T1DM planning pregnancy or at the beginning of pregnancy, keeping in mind that serum TSH levels should be in the range of $0.2-2.5 \mathrm{mUI} / \mathrm{L}$ in the first trimester.

(2)

We suggest screening for gestational diabetes if TSH is higher than the normal trimester-specific values in the first part of pregnancy.

(3)

In case of positive TPOAbs and normal serum TSH during pregnancy, TSH levels should be checked at 3, 6, and 12 months after delivery.

\section{Association of thyroid dysfunction and T1DM in children}

AITD, especially Hashimoto's thyroiditis, is the most common immune process in children and adolescents with T1DM [24, 32, 35, 39, 40, 85, 137]. Most patients are asymptomatic at diagnosis; altered (overt or subclinical) thyroid function occurs only in a few subjects, $80 \%$ of which are hypothyroid and $20 \%$ hyperthyroid [70]. AITD appears to be related to the onset of T1DM in prepubertal patients, and the clinical features of diabetes are more severe as compared to diabetics without AITD. These data highlight the importance of screening for AITD in T1DM, paying particular attention to prepubertal age [120].

Subclinical hypothyroidism is associated to an increased risk of symptomatic hypoglycemia. The correction of hypothyroidism improves metabolic control, reducing hypoglycemic events [70]. Data concerning the association between Graves' disease and T1DM in childhood and adolescence are limited [24, 32, 35, 39, $40,137]$.

\section{Indications for clinical practice}

(1)

We suggest screening for AITD (TSH, TPOAb, TgAb, followed by possible thyroid ultrasound) in the pediatric population with T1DM.

We do not recommend the periodic determination of TRAb in T1DM. 
Multinodular goiter is reportedly increased in T2DM patients $[138,139]$. However, the risk of thyroid cancer is not increased in individuals with DM [140-142].

\section{Indications for clinical practice}

(1)

We so not suggest routine ultrasound screening of the thyroid gland in T2DM patients at diagnosis.

We recommend that the diagnostic evaluation of nodular thyroid disease in diabetic patients follow the guidelines as for the general population.

\section{Treatment of diabetes and thyroid function}

Some drugs used in the treatment of diabetes can affect thyroid function. Thyroid dysfunction, on the other hand, may affect the therapy of diabetes.

\section{Metformin}

A correlation between metformin (the first-choice drug for T2DM [143]) and the onset of hypothyroidism in euthyroid patients with T2DM has been reported. Patients treated with metformin exhibited significantly higher TSH values than untreated patients. However, metformin therapy no longer appeared as an independent predictor when other variables such as BMI, hyperlipidemia, and macrovascular diabetic complications were included in multiple regression analysis [71]. In diabetic patients with primary hypothyroidism, a slow decline in plasma TSH levels was reported a few months after metformin treatment began, which was not associated with alterations in plasma FT4 and FT3 concentrations. This decline is reversible after metformin discontinuation and does not occur in euthyroid subjects [144-147]. Therefore, although the actual effect of metformin is yet to be determined, TSH levels in hypothyroid patients should be monitored in the 12 months after beginning metformin treatment.

Thyroid cancer size is reportedly smaller in patients treated with metformin, possibly suggesting druginduced inhibition of tumor growth. The absence of metformin therapy might represent an independent factor for a decreased likelihood of cancer and increased risk of shorter progression-free survival [148].

\section{Sulfonylureas (SU)}

Anti-thyroid and "goitrogen" effects were reported in patients on SU therapy. Such effects can be caused by a reduction of iodine uptake induced by first-generation SU (carbutamide, chlorpropamide, and tolbutamide). Moreover, thyroid volume reportedly increased with reduced iodine uptake after 4 months' treatment with gliclazide [149-154]. Such data, however, should not be currently regarded as a contraindication to SU therapy in patients with nodular thyroid disease.

\section{Glitazones}

Exacerbation of GO was described in patients with T2DM following treatment with glitazones apparently not associated with changes in thyroid functional status [155]. Interruption of pioglitazone treatment did 
not result in remission of GO. Hence, GO worsening cannot be attributed to glitazone-induced edema. In vitro, treatment with pioglitazone induced a two- to eightfold increase in the rate of differentiation of preadipocytes in orbital adipose tissue. Thus, thiazolidinediones should be administered with caution in diabetic patients with active GO [155-158]. Rosiglitazone therapy might reduce thyroid cancer risk in patients with T2DM [159].

\section{Incretin mimetics}

Preclinical studies in animal models have shown an association between treatment with exenatide or liraglutide and the appearance of abnormalities of thyroid C cells, with progressive development of hyperplasia and adenomas. The lesions were preceded by an increase in plasma calcitonin levels. In clinical studies in humans, no significant changes in calcitonin levels were observed in treated patients as compared to controls. The absence of such an event in humans is likely due to greater sensitivity and density of glucagon-like peptide (GLP)-1 receptors in rat C cells as well as the high dosage employed in animal models. Liraglutide, however, is not recommended in patients with a personal or family history of medullary thyroid carcinoma or type 2 multiple endocrine neoplasia (MEN-2) [160-164].

\section{Insulin}

Insulin therapy does not appear to cause alterations in thyroid function. Insulin requirements increase in insulin-treated patients developing thyrotoxicosis $[12,165]$. On the contrary, insulin requirements decrease in insulin-treated patients developing hypothyroidism resulting from lower intestinal glucose absorption and reduced hepatic glucose production. Therefore, a reduction in insulin dose should be considered to prevent hypoglycemia, and doses should be modulated with the correction of hypothyroidism $[12,70,165]$.

\section{Treatment of thyroid disease and diabetes}

Excessive l-thyroxine therapy may induce iatrogenic hyperthyroidism determining impaired glycemic metabolism. It does not appear that anti-thyroid drugs determine an appreciable effect on glycemic control, apart from a possible iatrogenic hypothyroidism. The use of ß-blockers in thyrotoxicosis may adversely affect hypoglycemia awareness in the diabetic patient $[166,167]$. Corticosteroids used as treatment of GO, or to prevent its exacerbation after the administration of 131-I, may result in worsening of glycemic control or in the onset of an iatrogenic form of diabetes.

\section{Indications for clinical practice}

(1)

We recommend re-evaluating the thyroid profile in 6-12 months after starting treatment with metformin in diabetic patients suffering from primary hypothyroidism on l-thyroxine.

There is insufficient evidence on whether to suggest performing a check of serum TSH and FT4 levels and a thyroid ultrasound in patients treated with SU.

We do not recommend administering pioglitazone to diabetic patients with GO. 
(4)

We recommend taking into careful consideration the negative effects on metabolic control that may be induced by corticosteroid therapy in case of onset/exacerbation of GO.

(5)

We recommend avoiding GLP-1 analogs in individuals with a personal or family history of medullary thyroid carcinoma or MEN-2.

(6)

We recommend re-evaluating insulin requirements in patients with hypothyroidism in light of increased hypoglycemic risk.

(7)

We recommend that special precautions for thyrotoxicosis be taken in diabetic patients during ß-blocker therapy because of the associated increased risk of hypoglycemia unawareness.

\section{References}

1.

GRADE Working Group website http://www.gradeworkinggroup.org.

2.

D. Atkins, D. Best, P.A. Briss, M. Eccles, Y. Falck-Ytter, S. Flottorp, G.H. Guyatt, R.T. Harbour, M.C. Haugh, D. Henry, S. Hill, R. Jaeschke, G. Leng, A. Liberati, N. Magrini, J. Mason, P. Middleton, J. Mrukowicz, D. O'Connell, A.D. Oxman, B. Phillips, H.J. Schünemann, T. Edejer, H. Varonen, G.E. Vist, J.W. Williams Jr, S. Zaza, GRADE Working Group, Grading quality of evidence and strength of recommendations. BMJ 328(7454), 1490 (2004).

3.

B.A. Swiglo, M.H. Murad, H.J. Schünemann, R. Kunz, R.A. Vigersky, G.H. Guyatt, V.M. Montori, A case for clarity, consistency, and helpfulness: state-of-the-art clinical practice guidelines in endocrinology using the grading of recommendations, assessment, development, and evaluation system. J. Clin. Endocrinol. Metab. 93(3), 666-673 (2008).

4. 
G.H. Guyatt, A.D. Oxman, G.E. Vist, R. Kunz, Y. Falck-Ytter, P. Alonso-Coello, H.J. Schünemann, GRADE Working Group, GRADE: an emerging consensus on rating quality of evidence and strength of recommendations. BMJ 336(7650), 924-926 (2008).

5.

J.I. Mechanick, P.M. Camacho, R.H. Cobin, A.J. Garber, J.R. Garber, H. Gharib, S.M. Petak, H.W. Rodbard, D.L. Trence, American Association of Clinical Endocrinologists, Protocol for standardized production of clinical practice guidelines-2010 update. Endocr. Pract. 16(2), 270-283 (2010).

6.

M.P.J. Vanderpump, The epidemiology of thyroid diseases, in Werner and Ingbar's the thryoid: a fundamental and clinical text, ed. by L.E. Braverman, R.D. Utiger (J.B. Lippicott-Raven, Philadelphia, 2005), pp. 398-496

7.

F. Aghini-Lombardi, L. Antonangeli, E. Martino, P. Vitti, D. Maccherini, F. Leoli, T. Rago, L. Grasso, R. Valeriano, A. Balestrieri, A. Pinchera, The spectrum of thyroid disorders in an iodine-deficient community: the Pescopagano survey. J Clin. Endocrinol. Metab. 84(2), 561-566 (1999).

8.

W.M. Tunbridge, D.C. Evered, R. Hall, D. Appleton, M. Brewis, F. Clark, J.G. Evans, E. Young, T. Bird, P.A. Smith, The spectrum of thyroid disease in a community: the Whickham survey. Clin. Endocrinol. (Oxford) 7(6), 481-493 (1977).

9.

M.P. Vanderpump, W.M. Tunbridge, J.M. French, D. Appleton, D. Bates, F. Clark, J. Grimley Evans, D.M. Hasan, H. Rodgers, F. Tunbridge, E.T. Young, The incidence of thyroid disorders in the community: a twentyyear follow-up of the Whickham Survey. Clin. Endocrinol. (Oxford) 43(1), 55-68 (1995).

10.

J.V. Parle, J.A. Franklyn, K.W. Cross, S.C. Jones, M.C. Sheppard, Prevalence and follow-up of abnormal thyrotrophin (TSH) concentrations in the elderly in the United Kingdom. Clin. Endocrinol. (Oxford) 34(1), 77-83 (1991).

11.

ISTAT (2012) www.istat.it/it/archivio/71090.

12.

M. Mouradian, N. Abourizk, Diabetes mellitus and thyroid disease. Diabetes Care 6(5), 512-520 (1983).

13.

R.S. Gray, W.J. Irvine, B.F. Clarke, Screening for thyroid dysfunction in diabetics. Br. Med. J. 2(6202), 1439 (1979). 
14.

L.H. Duntas, J. Orgiazzi, G. Brabant, The interface between thyroid and diabetes mellitus. Clin. Endocrinol. (Oxford) 75(1), 1-9 (2011).

15.

R. Kadiyala, R. Peter, O.E. Okosieme, Thyroid dysfunction in patients with diabetes: clinical implications and screening strategies. Int. J. Clin. Pract. 64(8), 1130-1139 (2010).

16.

P. Perros, R.J. McCrimmon, G. Shaw, B.M. Frier, Frequency of thyroid dysfunction in diabetic patients: value of annual screening. Diabet. Med. 12(7), 622-627 (1995)

17.

G.E. Umpierrez, K.A. Latif, M.B. Murphy, H.C. Lambeth, F. Stentz, A. Bush, A.E. Kitabch, Thyroid dysfunction in patients with type 1 diabetes: a longitudinal study. Diabetes Care 26(4), 1181-1185 (2003).

18.

L.C. de Graaff, J.W. Smit, J.K. Radder, Prevalence and clinical significance of organ-specific autoantibodies in type 1 diabetes mellitus. Neth. J. Med. 65(7), 235-247 (2007).

19.

J.M. Moore, J.M. Neilson, Antibodies to gastric mucosa and thyroid in diabetes mellitus. Lancet. 2(7309), 645-647 (1963).

20.

D.E. Goldstein, A. Drasch, J. Gibbs, R.M. Blizzard, Diabetes mellitus: the incidence of circulating antibodies against thyroid, gastric, and adrenal tissue. J. Pediatr. 77(2), 304-306 (1970).

21.

W.J. Irvine, B.F. Clarke, L. Scarth, D.R. Cullen, L.J. Duncan, Thyroid and gastric autoimmunity in patients with diabetes mellitus. Lancet 2(7665), 163-168 (1970)

22.

J. Nerup, C. Binder, Thyroid, gastric and adrenal auto-immunity in diabetes mellitus. Acta. Endocrinol. (Copenh) 72(2), 279-286 (1973).

23.

M. Neufeld, N.K. Maclaren, W.J. Riley, D. Lezotte, J.V. McLaughlin, J. Silverstein, A.L. Rosenbloom, Islet cell and other organ-specific antibodies in U.S. Caucasians and Blacks with insulin-dependent diabetes mellitus. Diabetes 29(8), 589-592 (1980).

24. 
W.J. Riley, N.K. Maclaren, D.C. Lezotte, R.P. Spillar, A.L. Rosenbloom, Thyroid autoimmunity in insulindependent diabetes mellitus: the case for routine screening. J. Pediatr. 99(3), 350-354 (1981).

25.

S. Court, J.M. Parkin, Hypothyroidism and growth failure in diabetes mellitus. Arch. Dis. Child. 57, 622-624 (1982).

26.

J. Kokkonen, J. Kiuttu, A. Mustonen, O. Räsänen, Organ-specific antibodies in healthy and diabetic children and young adults. Acta. Pediatr. Scand. 71(2), 223-226 (1982).

27.

B.B. Gilani, M.H. MacGillivray, M.L. Voorhess, B.J. Mills, W.J. Riley, N.K. MacLaren, Thyroid hormone abnormalities at diagnosis of insulin-dependent diabetes mellitus in children. J. Pediatr. 105(2), 218-222 (1984).

28.

N.K. Maclaren, W.J. Riley, Thyroid, gastric, and adrenal autoimmunities associated with insulin-dependent diabetes mellitus. Diabetes Care 8(Suppl 1), 34-38 (1985).

29.

D.W. Drell, A.L. Notkins, Multiple immunological abnormalities in patients with Type 1 (insulin-dependent) diabetes mellitus. Diabetologia. 30(3), 132-143 (1987).

30.

S. Kontiainen, A. Schlenzka, S. Koskimies, A. Rilva, J. Mäenpää, Autoantibodies and autoimmune diseases in young diabetics. Diabetes Res. 13(4), 151-156 (1990).

31.

M. Landin-Olsson, F.A. Karlsson, A. Lernmark, G. Sundkvist, Islet cell and thyrogastric antibodies in 633 consecutive 15- to 34-yr-old patients in the diabetes incidence study in Sweden. Diabetes 41(8), 1022-1027 (1992).

32.

G. Radetti, C. Paganini, L. Gentili, S. Bernasconi, C. Betterle, M. Borkenstein, K. Cvijovic, M. KadrnkaLovrencic, C. Krzisnik, T. Battelino, R. Lorini, S. Marinoni, F. Rigon, L. Tatò, L. Pinelli, G. Tonini, Frequency of Hashimoto's thyroiditis in children with type 1 diabetes mellitus. Acta Diabetol. 32(2), 121-124 (1995).

33.

P. Abrams, I. De Leeuw, J. Vertommen, In new-onset insulin-dependent diabetic patients the presence of anti-thyroid peroxidase antibodies is associated with islet cell autoimmunity and the high risk haplotype HLA DQA1*0301-DQB1*0302. Belgian Diabetes Registry. Diabet. Med. 13(5), 415-419 (1996).

34. 
I.G. Jefferson, The clinical approach to thyroid disorders associated with childhood insulin dependent diabetes mellitus. J. Pediatr. Endocrinol. Metab. 9(Suppl 1), 95-100 (1996).

35.

R. Lorini, G. d'Annunzio, L. Vitali, A. Scaramuzza, IDDM and autoimmune thyroid disease in the pediatric age group. J. Pediatr. Endocrinol. Metab. 9(Suppl 1), 89-94 (1996).

36.

F. Presotto, C. Betterle, Insulin-dependent diabetes mellitus: a constellation of autoimmune diseases. J. Pediatr. Endocrinol. Metab. 10(5), 455-469 (1997).

37.

E. McCanlies, L.A. O'Leary, T.P. Foley, M.K. Kramer, J.P. Burke, A. Libman, J.S. Swan, A.R. Steenkiste, B.J. Mccarthy, M. Trucco, J.S. Dorman, Hashimoto's thyroiditis and insulin-dependent diabetes mellitus: differences among individuals with and without abnormal thyroid function. J. Clin. Endocrinol. Metab. 83(5), 1548-1551 (1998).

38.

C.C. Chang, C.N. Huang, L.M. Chuang, Autoantibodies to thyroid peroxidase in patients with type 1 diabetes in Taiwan. Eur. J. Endocrinol. 139(1), 44-48 (1998).

39.

D. Hansen, F.N. Bennedbaek, L.K. Hansen, M. Hoier-Madsen, B.B. Jacobsen, L. Hegedüs, Thyroid function, morphology and autoimmunity in young patients with insulin-dependent diabetes mellitus. Eur. J. Endocrinol. 140(6), 512-518 (1999).

40.

M.B. Roldán, M. Alonso, R. Barrio, Thyroid autoimmunity in children and adolescents with Type 1 diabetes mellitus. Diabetes Nutr. Metab. 12(1), 27-31 (1999).

41.

G. Gambelunghe, F. Forini, S. Laureti, G. Murdolo, G. Toraldo, F. Santeusanio, P. Brunetti, C.B. Sanjeevi, A. Falorni, Increased risk for endocrine autoimmunity in Italian type 2 diabetic patients with GAD65 autoantibodies. Clin. Endocrinol. (Oxford) 52(5), 565-573 (2000).

42.

C. Rattarasarn, M.A. Diosdado, J. Ortego, R. Leelawattana, S. Soonthornpun, W. Setasuban, S. Jaruratanasirikul, N. Patarakijvanich, Thyroid autoantibodies in Thai type 1 diabetic patients: clinical significance and their relationship with glutamic acid decarboxylase antibodies. Diabetes Res. Clin. Pract. 49(2-3), 107-111 (2000).

43. 
C.E. De Block, I.H. De Leeuw, J.J. Vertommen, R.P. Rooman, M.V. Du Caju, C.M. Van Campenhout, J.J. Weyler, F. Winnock, J. Van Autreve, F.K. Gorus, Belgian Diabetes Registry, Beta-cell, thyroid, gastric, adrenal and coeliac autoimmunity and HLA-DQ types in type 1 diabetes. Clin. Exp. Immunol. 126(2), 236-241 (2001).

44.

O. Kordonouri, A. Klinghammer, E.B. Lang, A. Grüters-Kieslich, M. Grabert, R.W. Holl, Thyroid autoimmunity in children and adolescents with type 1 diabetes: a multicenter survey. Diabetes Care 25(8), 1346-1350 (2002).

45.

H. Bárová, J. Perusicová, M. Hill, I. Sterzl, K. Vondra, Z. Masek, Anti-GAD-positive patients with type 1 diabetes mellitus have higher prevalence of autoimmune thyroiditis than anti-GAD-negative patients with type 1 and type 2 diabetes mellitus. Physiol. Res. 53(3), 279-286 (2004).

46.

M. Prázný, J. Skrha, Z. Límanová, Z. Vanícková, J. Hilgertová, J. Prázná, M. Jaresová, I. Stríz, Screening for associated autoimmunity in type 1 diabetes mellitus with respect to diabetes control. Physiol. Res. 54(1), 41-48 (2005).

47.

K. Vondra, J. Vrbíková, B. Bendlová, K. Dvorakova, I. Sterzl, M. Vondrova, Differences in type I diabetes mellitus of young adults with and without thyroid autoimmunity. Exp. Clin. Endocrinol. Diabetes 113(7), 404-408 (2005).

48.

J.M. Barker, J. Yu, L. Yu, J. Wang, D. Miao, F. Bao, E. Hoffenberg, J.C. Nelson, P.A. Gottlieb, M. Rewers, G.S. Eisenbarth, Autoantibody "subspecificity" in type 1 diabetes: risk for organ-specific autoimmunity clusters in distinct groups. Diabetes Care 28(4), 850-855 (2005).

49.

H. Völzke, U. Krohn, H. Wallaschofski, J. Lüdemann, U. John, W. Kerner, The spectrum of thyroid disorders in adult type 1 diabetes mellitus. Diabetes Metab. Res. Rev. 23(3), 227-233 (2007).

50.

R.M. Mantovani, L.M. Mantovani, V.M. Dias, Thyroid autoimmunity in children and adolescents with type 1 diabetes mellitus: prevalence and risk factors. J. Pediatr. Endocrinol. Metab. 20(6), 669-675 (2007).

51.

K. Warncke, E.E. Fröhlich-Reiterer, A. Thon, S.E. Hofer, D. Wiemann, R.W. Holl, DPV Initiative of the German Working Group for Pediatric Diabetology, German BMBF Competence Network for Diabetes Mellitus, DPV Initiative of the German Working Group for Pediatric Diabetology, German BMBF Competence Network for Diabetes Mellitus, Polyendocrinopathy in children, adolescents, and young adults with type 1 diabetes: a 
multicenter analysis of 28,671 patients from the German/Austrian DPV-Wiss database. Diabetes Care 33(9), 2010-2012 (2010).

52.

R. Volpé, Autoimmunity in the Endocrine System, in Monographs on Endocrinology (Springer-Verlag, BerlinHeidelberg-New York, (1981)), pp. 19-111.

53.

D. Maugendre, F. Vérité, I. Guilhem, B. Genetet, H. Allannic, M. Delamaire, Anti-pancreatic autoimmunity and Graves' disease: study of a cohort of 600 Caucasian patients. Eur. J. Endocrinol. 137(5), 503-510 (1997).

54.

R. Kalmann, M.P. Mourits, Diabetes mellitus: a risk factor in patients with Graves' orbitopathy. Br. J. Ophthalmol. 83(4), 463-465 (1999).

55.

W.J. Irvine, C.J. McCallum, R.S. Gray, C.J. Campbell, L.J. Duncan, J.W. Farquhar, H. Vaughan, P.J. Morris, Pancreatic islet-cell antibodies in diabetes mellitus correlated with the duration and type of diabetes coexistent autoimmune disease, and HLA type. Diabetes 26(2), 138-147 (1977).

56.

G.M. Bright, R.M. Blizzard, D.L. Kaiser, W.L. Clarke, Organ-specific autoantibodies in children with common endocrine diseases. J. Pediatr. 100(1), 8-14 (1982).

57.

C. Betterle, F. Presotto, B. Pedini, L. Moro, R.S. Slack, F. Zanette, R. Zanchetta, Islet cell and insulin autoantibodies in organ-specific autoimmune patients. Their behaviour and predictive value in the development of type 1 (insulin-dependent) diabetes mellitus. A ten year follow-up study. Diabetologia 30(5), 292-297 (1987).

58.

Y. Yamaguchi, N. Chikuba, Y. Ueda, H. Yamamoto, H. Yamasaki, T. Nakanishi, S. Akazawa, S. Nagataki, Islet cell antibodies in patients with autoimmune thyroid diseases. Diabetes 40(3), 319-322 (1991).

59.

C. Betterle, F. Presotto, L. Magrin, B. Pedini, L. Moro, A. Caretto, R. Zanchetta, The natural history of pretype 1 (insulin-dependent) diabetes mellitus in patients with autoimmune endocrine diseases. Diabetologia 37(1), 95-103 (1994).

60.

B. Hallengren, A. Falorni, M. Landin-Olsson, A. Lernmark, K.I. Papadopoulos, G. Sundkvist, Islet cell and glutamic acid decarboxylase antibodies in hyperthyroid patients at diagnosis and following treatment. J. Intern. Med. 239(1), 63-68 (1996). 
61.

E. Kawasaki, N. Abiru, M. Yano, S. Uotani, K. Matsumoto, H. Matsuo, H. Yamasaki, H. Yamamoto, Y. Yamaguchi, S. Akazawa, Autoantibodies in patients with autoimmune thyroid disease: relation to competitive insulin antibodies. J. Autoimmun. 8(5), 633-643 (1995).

62.

D.Y. Aksoy, B.P. Yürekli, B.O. Yildiz, O. Gedik, Prevalence of glutamic acid decarboxylase antibody positivity and its association with insulin secretion and sensitivity in autoimmune thyroid disease: a pilot study. Exp.

Clin. Endocrinol. Diabetes 114(8), 412-416 (2006). (LoE） PubMedGoogle Scholar

63.

M. Pietropaolo, J.C. Hutton, G.S. Eisenbarth, Protein thyrosine phoshatase-like proteins: link with IDDM. Diabetes Care 20(2), 208-214 (1997).

64.

N.G. Morgenthaler, J. Seissler, P. Achenbach, D. Glawe, M. Payton, H.M. Meinck, M.R. Christie, W.A. Scherbaum, Antibodies to the tyrosine phosphatase-like protein IA-2 are highly associated with IDDM, but not with autoimmune endocrine diseases or Stiff man syndrome. Autoimmunity 25(4), 203-211 (1997).

65.

E. Bosi, F. Becker, E. Bonifacio, R. Wagner, P. Collins, E.A. Gale, G. Bottazzo, Progression to type 1 diabetes in autoimmune endocrine patients with islet cell antibodies. Diabetes. 40(8), 977-984 (1991).

66.

C.M. Tudela, B.M. Casey, D.D. McIntire, F.G. Cunningham, Relationship of subclinical thyroid disease to the incidence of gestational diabetes. Obstet. Gynecol. 119(5), 983-988 (2012).

67.

C. Betterle, A.C. Spadaccino, F. Presotto, R. Zanchetta, B. Pedini, M. Lai, N.A. Greggio, G.F. Bottazzo, The number of markers of pancreatic autoimmunity increases the risk for type 1 diabetes mellitus (DM) in Italian and English patients with organ-specific autoimmune diseases (OSAD). Ann. N. Y. Acad. Sci. 958, 276-280 (2002).

68.

A.R. Radaideh, M.K. Nusier, F.L. Amari, A.E. Bateiha, M.S. El-Khateeb, A.S. Naser, K.M. Ajlouni, Thyroid dysfunction in patients with type 2 diabetes mellitus in Jordan. Saudi Med. J. 25(8), 1046-1050 (2004).

69.

S.A.P. Chubb, W.A. Davis, Z. Inman, T.M. Davis, Prevalence and progression of subclinical hypothyroidism in women with type 2 diabetes: the Fremantle Diabetes Study. Clin. Endocrinol. (Oxford) 62(4), 480-486 (2005). 
A. Mohn, S. Di Michele, R. Di Luzio, S. Tumini, F. Chiarelli, The effect of subclinical hypothyroidism on metabolic control in children and adolescents with type 1 diabetes mellitus. Diabet. Med. 19(1), 70-73 (2002).

71.

J.J. Díez, P. Iglesias, An analysis of the relative risk for hypothyroidism in patients with Type 2 diabetes. Diabet. Med. 29(12), 1510-1514 (2012).

72.

J.J. Díez, P. Iglesias, Subclinical hyperthyroidism in patients with type 2 diabetes. Endocrine 42(1), 157-163 (2012).

73.

B. Gopinath, J.J. Wang, A. Kifley, J.R. Wall, S.R. Leeder, P. Mitchell, Type 2 diabetes does not predict incident thyroid dysfunction in the elderly. Diabetes Res. Clin. Pract. 82(3), e11-e13 (2008).

74.

J.J. Díez, P. Sánchez, P. Iglesias, Prevalence of thyroid dysfunction in patients with type 2 diabetes. Exp. Clin. Endocrinol. Diabetes 119(4), 201-207 (2011).

75.

A. Huber, F. Menconi, S. Corathers, E.M. Jacobson, Y. Tomer, Joint genetic susceptibility to type 1 diabetes and autoimmune thyroiditis: from epidemiology to mechanisms. Endocr. Rev. 29(6), 697-725 (2008).

76.

E.C. Somers, S.L. Thomas, L. Smeeth, A.J. Hall, Autoimmune diseases co-occurring within individuals and within families: a systematic review. Epidemiology 17(2), 202-217 (2006).

77.

P.R. Gallas, R.P. Stolk, K. Bakker, E. Endert, W.M. Wiersinga, Thyroid dysfunction during pregnancy and in the first postpartum year in women with diabetes mellitus type 1. Eur. J. Endocrinol. 147(4), 443-451 (2002).

78.

A. Hanukoglu, A. Mizrachi, I. Dalal, O. Admoni, Y. Rakover, Z. Bistritzer, A. Levine, E. Somekh, D. Lehmann, M. Tuval, M. Boaz, A. Golander, Extrapancreatic autoimmune manifestations in type 1 diabetes patients and their first-degree relatives: a multicenter study. Diabetes Care. 26(4), 1235-1240 (2003).

79.

G.C. Gonzàles, I. Capel, J. Rodríguez-Espinosa, D. Mauricio, A. de Leiva, A. Pérez, Thyroid autoimmunity at onset of type 1 diabetes as a predictor of thyroid dysfunction. Diabetes Care 30(6), 1611-1612 (2007). 
80.

O. Kordonouri, D. Deiss, T. Danne, A. Dorow, C. Bassir, A. Grüters-Kieslich, Predictivity of thyroid autoantibodies for the development of thyroid disorders in children and adolescents with type 1 diabetes.

Diabet. Med. 19(6), 518-521 (2002).

81.

O. Kordonouri, R. Hartmann, D. Deiss, M. Wilms, A. Grüters-Kieslich, Natural course of autoimmune thyroiditis in type 1 diabetes: association with gender, age, diabetes duration, and puberty. Arch. Dis. Child. 90(4), 411-414 (2005).

82.

B. Lindberg, U.B. Ericsson, R. Ljung, S.A. Ivarsson, High prevalence of thyroid autoantibodies at diagnosis of insulin-dependent diabetes mellitus in Swedish children. J. Lab. Clin. Med. 130(6), 585-589 (1997).

83.

M.J.B. Villano, A.K. Huber, D.A. Greenberg, B.K. Golden, E. Concepcion, Y. Tomer, Autoimmune thyroiditis and diabetes: dissecting the joint genetic susceptibility in a large cohort of multiplex families. J. Clin. Endocrinol. Metab. 94(4), 1458-1466 (2009).

84.

S.H. Pearce, T.R. Merriman, Genetics of type 1 diabetes and autoimmune thyroid disease. Endocrinol. Metab. Clin. North. Am. 38(2), 289-301 (2009).

85.

A. Van den Driessche, V. Eenkhoorn, L. Van Gaal, C. De Block, Type 1 diabetes and autoimmune polyglandular syndrome: a clinical review. Neth. J. Med. 67(11), 376-387 (2009).

86.

J.M. Barker, Clinical review: type 1 diabetes-associated autoimmunity: natural history, genetic associations, and screening. J. Clin. Endocrinol. Metab. 91(4), 1210-1217 (2006).

87.

G.S. Eisenbarth, P.A. Gottlieb, Autoimmune polyendocrine syndromes. N. Engl. J. Med. 350(20), 2068-2079 (2004).

88.

American Diabetes Association, Standards of Medical Care in Diabetes 2012. Diabetes Care 35(Suppl 1), S11-S63 (2012).

89.

Canadian Diabetes Association Clinical Practice Guidelines Expert Committee, Canadian Diabetes Association 2013 clinical practice guidelines for the prevention and management of diabetes in Canada. Can. J. Diabetes 37(suppl 1), S1-S212 (2013). 
90.

J.M. Dora, W.E. Machado, J. Rheinheimer, D. Crispim, A.L. Maia, Association of the type 2 deiodinase Thr92Ala polymorphism with type 2 diabetes: case-control study and meta-analysis. Eur. J. Endocrinol. 163(3), 427-434 (2010).

91.

H.R. Maxon, K.W. Kreines, R.E. Goldsmith, H.C. Knowles Jr, Long-term observations of glucose tolerance in thyrotoxic patients. Arch. Intern. Med. 135(11), 1477-1480 (1975).

92.

M. Hage, M.S. Zantout, S.T. Azar, Thyroid disorders and diabetes mellitus. J. Thyroid Res. 2011, 439463 (2011).

93.

P. Cavallo-Perin, A. Bruno, L. Boine, M. Cassader, G. Lenti, G. Pagano, Insulin resistance in Graves' disease: a quantitative in vivo evaluation. Eur. J. Clin. Invest. 18(6), 607-613 (1988).

94.

E. Maratou, D.J. Hadjidakis, M. Peppa, M. Alevizaki, K. Tsegka, V. Lambadiari, P. Mitrou, E. Boutati, A. Kollias, T. Economopoulos, S.A. Raptis, G. Dimitriadis, Studies of insulin resistance in patients with clinical and subclinical hyperthyroidism. Eur. J. Endocrinol. 163(4), 625-630 (2010).

95.

P. Mitrou, E. Boutati, V. Lambadiari, A. Tsegka, A.E. Raptis, N. Tountas, T. Economopoulos, S.A. Raptis, G. Dimitriadis, Insulin resistance in hyperthyroidism: the role of IL6 and TNF alpha. Eur. J. Endocrinol. 162(1), 121-126 (2010).

96.

A. Bhattacharyya, P.G. Wiles, Diabetic ketoacidosis precipitated by thyrotoxicosis. Postgrad. Med. J. 75(883), 291-292 (1999).

97.

K.A. Al-Shoumer, B.A. Vasanthy, M.M. Al-Zaid, Effects of treatment of hyperthyroidism on glucose homeostasis, insulin secretion, and markers of bone turnover. Endocr. Pract. 12(2), 121-130 (2006).

98.

E. Solà, C. Morillas, S. Garzón, M. Gómez-Balaguer, A. Hernández-Mijares, Association between diabetic ketoacidosis and thyrotoxicosis. Acta. Diabetol. 39(4), 235-237 (2002).

99.

M. Kunishige, E. Sekimoto, M. Komatsu, Y. Bando, H. Uehara, K. Izumi, Thyrotoxicosis masked by diabetic ketoacidosis: a fatal complication. Diabetes Care 24(1), 171 (2001). 
100.

R. Naeije, J. Golstein, N. Clumeck, H. Meinhold, K.W. Wenzel, L. Vanhaelst, A low T3 syndrome in diabetic ketoacidosis. Clin. Endocrinol. (Oxford) 8(6), 467-472 (1978).

101.

K.K. Boelaert, J.A. Franklyn, Thyroid hormone in health and disease. J. Endocrinol. 187(1), 1-15 (2005).

102.

J.A. Franklin, P. Maisonneuve, M.C. Sheppard, J. Betteridge, P. Boyle, Mortality after the treatment of hyperthyroidism with radioactive iodine. N. Engl. J. Med. 338(11), 712-718 (1998).

103.

S.W. Moon, J.R. Hahm, G.W. Lee, M.Y. Kang, J.H. Jung, T.S. Jung, K.W. Lee, K.A. Jung, Y.J. Ahn, S. Kim, M.A. Kim, D.R. Kim, S.I. Chung, M.H. Park, A case of hyperglycemic hyperosmolar state associated with Graves' hyperthyroidism: a case report. J. Korean Med. Sci. 21(4), 765-767 (2006).

104.

M.F. Celani, M.E. Bonati, N. Stucci, Prevalence of abnormal thyrotropin concentrations measured by a sensitive assay in patients with type 2 diabetes mellitus. Diabetes Res. 27(1), 15-25 (1994).

105.

E. Maratou, D.J. Hadjidakis, A. Kollias, K. Tsegka, M. Peppa, M. Alevizaki, P. Mitrou, V. Lambadiari, E. Boutati, D. Nikzas, N. Tountas, T. Economopoulos, S.A. Raptis, G. Dimitriadis, Studies of insulin resistance in patients with clinical and subclinical hypothyroidism. Eur. J. Endocrinol. 160(5), 785-790 (2009).

106.

G. Brenta, F.S. Celi, M. Pisarev, M. Schnitman, I. Sinay, P. Arias, Acute thyroid hormone withdrawal in athyreotic patients results in a state of insulin resistance. Thyroid 19(6), 665-669 (2009).

107.

H. Debiec, H.S. Cross, M. Peterlik, d-glucose uptake is increased in jejunal brush-border membrane vesicles from hyperthyroid chicks. Acta. Endocrinol. (Copenh) 120(4), 435-441 (1989).

108.

A.R. Cappola, P.W. Ladenson, Hypothyroidism and atherosclerosis. J. Clin. Endocrinol. Metab. 88(6), 24382444 (2003).

109.

L. Duntas, G. Kolovou, Options for the treatment of hyperlipidemia in type 2 diabetes mellitus and hypothyroidism: lowering the cardiovascular risk. Future Cardiol. 7(2), 137-144 (2011).

110. 
E. Yeter, T. Keles, T. Durmaz, E. Bozkurt, Rhabdomyolysis due to the additive effect of statin therapy and hypothyroidism: a case report. J. Med. Case Rep. 1, 130 (2007).

111.

K. Tokinaga, T. Oeda, Y. Suzuki, Y. Matsushima, HMG-CoA reductase inhibitors (statins) might cause high elevations of creatine phosphokinase (CK) in patients with unnoticed hypothyroidism. Endocr. J. 53(3), 401405 (2006).

112.

M.P. Vanderpump, W.M. Tunbridge, J.M. French, D. Appleton, D. Bates, F. Clark, J. Grimley Evans, H. Rodgers, F. Tunbridge, E.T. Youn, The development of ischemic heart disease in relation to autoimmune thyroid disease in a 20-year follow-up study of an English community. Thyroid 6(3), 155-160 (1996).

113.

S.A. Chubb, W.A. Davis, T.M. Davis, Interactions among thyroid function, insulin sensitivity, and serum lipid concentrations: the Fremantle diabetes study. J. Clin. Endocrinol. Metab. 90(9), 5317-5320 (2005).

114.

K.B. Kapadia, P.A. Bhatt, J.S. Shah, Association between altered thyroid state and insulin resistance. J. Pharmacol. Pharmacother. 3(2), 156-160 (2012).

115.

N. Knudsen, P. Laurberg, L.B. Rasmussen, I. Bülow, H. Perrild, L. Ovesen, T. Jørgensen, Small differences in thyroid function may be important for body mass index and the occurrence of obesity in the population. J. Clin. Endocrinol. Metab. 90(7), 4019-4024 (2005).

116.

N. Manji, K. Boelaert, M.C. Sheppard, R.L. Holder, S.C. Gough, J.A. Franklyn, Lack of association between serum TSH or free T4 and body mass index in euthyroid subjects. Clin. Endocrinol. (Oxford) 64(2), 125-128 (2006).

117.

K. Oboubie, J. Smith, L.M. Evans, R. John, J.S. Davies, J.H. Lazarus, Increased central arterial stiffness in hypothyroidism. J. Clin. Endocrinol. Metab. 87(10), 4662-4666 (2002).

118.

P.J. Owen, R. Sabit, J.H. Lazarus, Thyroid disease and vascular function. Thyroid 17, 519-524 (2007)

119.

R.S. Gray, D.Q. Borsey, W.J. Irvine, J. Seth, B.F. Clarke, Natural history of thyroid function in diabetics with impaired thyroid reserve: a four year controlled study. Clin. Endocrinol. (Oxford) 19(4), 445-451 (1983). 
A. Franzese, P. Buono, M. Mascolo, A.L. Leo, G. Valerio, Thyroid autoimmunity starting during the course of type 1 diabetes denotes a subgroup of children with more severe diabetes. Diabetes Care 23(8), 1201-1202 (2000).

121.

T. Sathyapalan, A.M. Manuchehri, A.S. Rigby, S.L. Atkin, Subclinical hypothyroidism is associated with reduced all-cause mortality in patients with type 2 diabetes. Diabetes Care 33(3), e37 (2010).

122.

A.E. Hak, H.A. Pols, T.J. Visser, H.A. Drexhage, A. Hofman, J.C. Witteman, Subclinical hypothyroidism is an independent risk factor for atherosclerosis and myocardial infarction in elderly women: the Rotterdam Study. Ann. Intern. Med. 132(4), 270-278 (2000).

123.

M.D. Danese, P.W. Ladenson, C.L. Meinert, N.R. Powe, Clinical review 115: effect of thyroxine therapy on serum lipoproteins in patients with mild thyroid failure: a quantitative review of the literature. J. Clin. Endocrinol. Metab. 85(9), 2993-3001 (2000).

124.

H.S. Chen, T.E. Wu, T.S. Jap, R.A. Lu, M.L. Wang, R.L. Chen, H.D. Lin, Subclinical hypothyroidism is a risk factor for nephropathy and cardiovascular diseases in type 2 diabetic patients. Diabet. Med. 24(12), 13361344 (2007).

125.

A.I. Katz, D.S. Emmanouel, M.D. Lindheimer, Thyroid hormone and the kidney. Nephron 15(3-5), 223-249 (1975).

126.

J.K. Yang, W. Liu, J. Shi, Y.B. Li, An association between subclinical hypothyroidism and sight-threatening diabetic retinopathy in type 2 diabetic patients. Diabetes Care 33(5), 1018-1020 (2010).

127.

G.R. Yang, J.K. Yang, L. Zhang, Y.H. An, J.K. Lu, Association between subclinical hypothyroidism and proliferative diabetic retinopathy in type 2 diabetic patients: a case-control study. Tohoku J. Exp. Med. 222(4), 303-310 (2010).

128.

R.G. Tilton, G. Pugliese, K. Chang, A. Speedy, M.A. Province, C. Kilo, J.R. Williamson, Effects of hypothyroidism on vascular $125 \mathrm{I}$-albumin permeation and blood flow in rats. Metabolism 38(5), 471-478 (1989).

129. 
S. Taddei, N. Caraccio, A. Virdis, A. Dardano, D. Versari, L. Ghiadoni, A. Salvetti, E. Ferrannini, F. Monzani, Impaired endothelium-dependent vasodilatation in subclinical hypothyroidism: beneficial effect of levothyroxine therapy. J. Clin. Endocrinol. Metab. 88(8), 3731-3737 (2003).

130.

L. Mutapcic, S.M. Wren, D.A. Leske, M.P. Fautsch, J.M. Holmes, The effect of I-thyroxine supplementation on retinal vascular development in neonatal rats. Curr. Eye Res. 30(12), 1035-1040 (2005).

131.

K.A. Toulis, A. Stagnaro-Green, R. Negro, Maternal subclinical hypothyroidism and gestational diabetes mellitus: a meta analysis. Endocr. Pract. 20(7), 703-714 (2014).

132.

H.C. Gerstein, Incidence of postpartum thyroid dysfunction in patients with type 1 diabetes mellitus. Ann. Intern. Med. 118(6), 419-423 (1993). (LoE IPubMedGoogle Scholar

133.

M. Vestgaard, L.R. Nielsen, A.K. Rasmussen, P. Damm, E.R. Mathiesen, Thyroid peroxidase antibodies in pregnant women with type 1 diabetes: impact on thyroid function, metabolic control and pregnancy outcome. Acta Obstet. Gynecol. Scand. 87(12), 1336-1342 (2008).

134.

A. Stagnaro-Green, Clinical review 152: postpartum thyroiditis. J. Clin. Endocrinol. Metab. 87(9), 4042-4047 (2002).

135.

P. Karakosta, D. Alegakis, V. Georgiou, T. Roumeliotaki, E. Fthenou, M. Vassilaki, D. Boumpas, E. Castanas, M. Kogevinas, L. Chatzi, Thyroid dysfunction and autoantibodies in early pregnancy are associated with increased risk of gestational diabetes and adverse birth outcomes. J. Clin. Endocrinol. Metab. 97(12), 44644472 (2012).

136.

L. De Groot, M. Abalovich, E.K. Alexander, N. Amino, L. Barbour, R.H. Cobin, C.J. Eastman, J.H. Lazarus, D. Luton, S.J. Mandel, J. Mestman, J. Rovet, S. Sullivan, Management of thyroid dysfunction during pregnancy and postpartum: an Endocrine Society clinical practice guideline. J. Clin. Endocrinol. Metab. 97(8), 25432565 (2012).

137.

M.J. McKenna, R. Herskowitz, J.I. Wolfsdorf, Screening for thyroid disease in children with IDDM. Diabetes Care 13(7), 801-803 (1990).

138. 
R. Junik, M. Kozinski, K. Debska-Kozinska, Thyroid ultrasound in diabetic patients without overt thyroid disease. Acta. Radiol. 47(7), 687-691 (2006).

139.

J.J. Díez, P. Iglesias, An analysis of the relative risk for goitre in euthyroid patients with type 2 diabetes. Clin. Endocrinol. (Oxford) 80(3), 356-361 (2014).

140.

C.M. Kitahara, E.A. Platz, L.E. Beane Freeman, A. Black, A.W. Hsing, M.S. Linet, Y. Park, C. Schairer, A. Berrington de González, Physical activity, diabetes, and thyroid cancer risk: a pooled analysis of five prospective studies (2012). Cancer Causes Control 23, 463-471 (2012).

141.

S.R. Shih, W.Y. Chiu, T.C. Chang, C.H. Tseng, Diabetes and thyroid cancer risk: literature review. Exp. Diabetes Res. 2012, 578285 (2012).

142.

C.H. Tseng, Thyroid cancer risk is not increased in diabetic patients. PLoS One 7(12), e53096 (2012). 143.

D.M. Nathan, J.B. Buse, M.B. Davidson, E. Ferrannini, R.R. Holman, R. Sherwin, B. Zinman, American Diabetes Association, European Association for the Study of Diabetes, Medical management of hyperglycaemia in type 2 diabetes mellitus: a consensus algorithm for the initiation and adjustment of therapy: a consensus statement from the American Diabetes Association and the European Association for the Study of Diabetes. Diabetologia 52(1), 17-30 (2009).

144.

R.A. Vigersky, A. Filmore-Nassar, A.R. Glass, Thyrotropin suppression by metformin. J. Clin. Endocrinol. Metab. 91(1), 225-227 (2006).

145.

M.L. Isidro, M.A. Penín, R. Nemiña, F. Cordido, Metformin reduces thyrotropin levels in obese, diabetic women with primary hypothyroidism on thyroxine replacement therapy. Endocrine 32(1), 79-82 (2007).

146.

C. Cappelli, M. Rotondi, I. Pirola, B. Agosti, E. Gandossi, U. Valentini, E. De Martino, A. Cimino, L. Chiovato, E. Agabiti-Rosei, M. Castellano, TSH-lowering effect of metformin in type 2 diabetic patients: differences between euthyroid, untreated hypothyroid, and euthyroid on I-T4 therapy patients. Diabetes Care 32(9), 1589-1590 (2009).

147.

J.J. Díez, P. Iglesias, Relationship between serum thyrotropin concentrations and metformin therapy in euthyroid patients with type 2 diabetes. Clin. Endocrinol. (Oxford) 78(4), 505-511 (2013). 
J. Klubo-Gwiezdzinska, J. Costello Jr, A. Patel, A. Bauer, K. Jensen, M. Mete, K.D. Burman, L. Wartofsky, V. Vasko, Treatment with metformin is associated with higher remission rate in diabetic patients with thyroid cancer. J. Clin. Endocrinol. Metab. 98(8), 3269-3279 (2013).

149.

R.E. Tranquada, D.H. Solomon, J. Brown, R. Greene, The effect of oral hypoglycemic agents on thyroid function in the rat. Endocrinology. 67, 293-297 (1960).

150.

J.M. Hershman, T.J. Craane, J.A. Colwell, Effect of sulfonylurea drugs on the binding of triiodothyronine and thyroxine to thyroxine-binding globulin. J. Clin. Endocrinol. Metab. 28(11), 1605-1610 (1968).

151.

C. Kilo, J. Dudley, B. Kalb, Evaluation of the efficacy and safety of Diamicron in non-insulin-dependent diabetic patients. Diabetes Res. Clin. Pract. 14(Suppl 2), S79-S82 (1991).

152.

M.L. England, J.M. Hartnell, J.M. Hershman, S.R. Levin, Glyburide does not alter thyroid function. Diabetes Res. 3(9), 471-474 (1986).

153.

S.W. Shen, R. Bressler, Clinical pharmacology of oral antidiabetic agents (second of two parts). N. Engl. J. Med. 296(14), 787-793 (1977).

154.

B. Efe, E. Entok, E. Güney, E. Erenoğlu, M. Kebapçı, Effects of second generation sulfonylureas on the thyroid. Turk J. Endocrinol. Metab. 4, 173-176 (1999).

155.

K. Starkey, A. Heufelder, G. Baker, W. Joba, M. Evans, S. Davies, M. Ludgate, Peroxisome proliferatoractivated receptor-gamma in thyroid eye disease: contraindication for thiazolidinedione use? J. Clin. Endocrinol. Metab. 88(1), 55-59 (2003).

156.

R. Menaka, M. Sehgal, M. Lakshmi, A. Bhattacharyya, Thiazolidinedione precipitated thyroid associated ophthalmopathy. J. Assoc. Physicians India 58, 255-257 (2010).

157.

S. Lee, A. Tsirbas, R.A. Goldberg, J.D. McCann, Thiazolidinedione induced thyroid associated orbitopathy. BMC Ophthalmol. 7, 8 (2007).

158. 
M. Dorkhan, M. Lantz, A. Frid, L. Groop, B. Hallengren, Treatment with a thiazolidinedione increases eye protrusion in a subgroup of patients with type 2 diabetes. Clin. Endocrinol. (Oxford) 65(1), 35-39 (2006).

159.

C.H. Tseng, Rosiglitazone may reduce thyroid cancer risk in patients with type 2 diabetes. Ann. Med. 45(8), 539-544 (2013).

160.

Byetta (Package insert) Amylin Pharmaceuticals Inc. San Diego (2007)

161.

Victoza US prescribing information (2010) www.victoza.com

162.

V.R. Aroda, R. Ratner, The safety and tolerability of GLP-1 receptor agonists in the treatment of type 2 diabetes: a review. Diabetes Metab. Res. Rev. 27(6), 528-542 (2011).

163.

D.J. Drucker, S.I. Sherman, R.M. Bergenstal, J.B. Buse, The safety of incretin-based therapies-review of the scientific evidence. J. Clin. Endocrinol. Metab. 96(7), 2027-2031 (2011).

164.

L. Hegedüs, A.C. Moses, M. Zdravkovic, T. Le Thi, G.H. Daniels, GLP-1 and calcitonin concentration in humans: lack of evidence of calcitonin release from sequential screening in over 5000 subjects with type 2 diabetes or nondiabetic obese subjects treated with the human GLP-1 analog, liraglutide. J. Clin. Endocrinol. Metab. 96(3), 853-860 (2011).

165.

J.L. Johnson, Diabetes control in thyroid disease. Diabetes Spectr. 19, 148-153 (2006).

166.

K. Helms, K. Kelley, Drug-induced hypoglycaemia. Cases and Occurrence. (2011) www.intechopen.com 167.

M.H. Murad, F. Coto-Yglesias, A.T. Wang, N. Sheidaee, R.J. Mullan, M.B. Elamin, P.J. Erwin, V.M. Montori, Clinical review: drug-induced hypoglycemia: a systematic review. J. Clin. Endocrinol. Metab. 94(3), 741-745 (2009). 